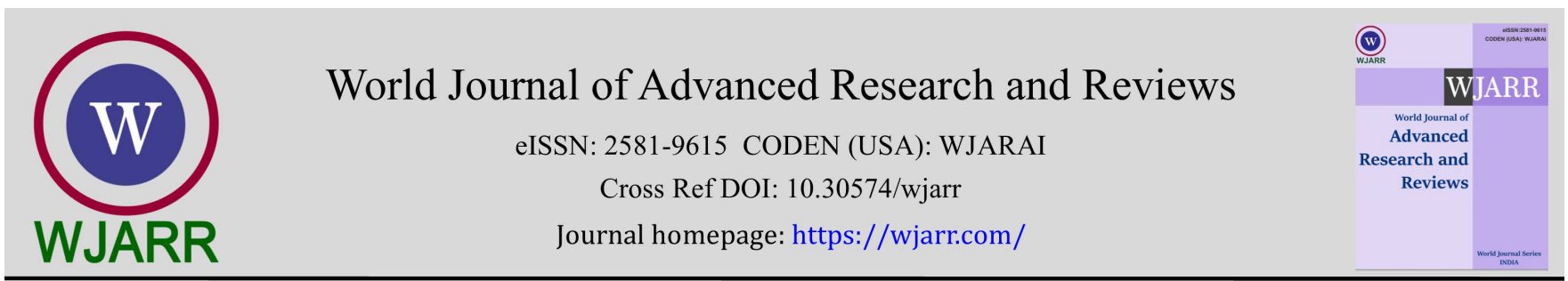

(RESEARCH ARTiClE)

\title{
Effect of different periods of irrigation on growth and yield of Cenchrus ciliaris at semi-arid zone of North Darfur State, Sudan
}

\author{
Mohamedalmontasir A. M. Mohamed ${ }^{1,{ }^{*}}$ and Mahmoud H. Mohamed 2 \\ ${ }^{1}$ Department of Range Science, Collage of Forestry and Range Science, University of East Kordofan, Sudan. \\ ${ }^{2}$ Soil and Water Research Program, Alfashir Research Station, Agricultural Research Corporation, Sudan.
}

World Journal of Advanced Research and Reviews, 2021, 09(02), 001-004

Publication history: Received on 05 January 2021; revised on 12 January 2021; accepted on 15 January 2021

Article DOI: https://doi.org/10.30574/wjarr.2021.9.2.0014

\begin{abstract}
Buffel grass Cenchrus ciliaris L. (Poaceae) is recognized as one of Australia's most serious environmental weeds. This introduced grass has been associated with loss of native species and alteration of fire regimes. However, it is also highly valued as a pasture species for arid and semi-arid zones and its weed status is highly controversial. This study was conducted at the private farm, Southern part of Alfashir Airport, North Darfur State, Sudan. The objective was to evaluate the effect of different periods of irrigation (DPI) on growth and forage yield of Cenchrus ciliaris during years of 2018 and 2019. The experiment was laid-out in a randomized complete block design (RCBD) with four replicates, the plot size was 8x5 m. Data collected included plant density, plant ground cover, plant height and dry matter yield. DPI showed significant effect on plant density, plant ground cover, Plant height and dry matter yield. The study showed that irrigation every 7 days (Ir1) was suitable for buffel grass at semi-arid zone in Sudan. Quantitative studies are needed to determine its ecological effects.
\end{abstract}

Keywords: Buffel grass; Dry matter yield; Irrigation periods; Plant height

\section{Introduction}

Sudan is rich in animal resources; these large animal resources contribute very much to the national economy through foreign earnings. The huge animal population of the country is kept under traditional nomadic systems and transhumance; animals greatly depend on the natural vegetation as their source of feed for maintenance and production. The productivity and total production of the Sudan rangelands declined very much due to the successive drought spells, allotment of rangelands to rainfed agriculture, accidental fires and the over burden of the increased animal population in these rangeland where the stocking rate is far in excess of the stock carrying capacity [1]. In order, to alleviate the pressure on rangeland, as well as to improve livestock production, t's necessary to encourage irrigated forage production through providing pasture seeds of good quality to guarantee provision of adequate forage supply which represents possible and feasible short term solution to the current feed supply problem. This entailed the uses of improved cultural practices and high yielding varieties [1]. Based on what was mentioned, buffel grass (Cenchrus ciliaris L.) is an economically important warm-season perennial used primarily as a forage and range grass in many of the drier regions throughout the subtropics and tropics. Its natural area of distribution is considered to be in the semi-arid areas extending from southern Africa to India [2]. Because buffel grass has excellent drought tolerance combined with desirable forage traits, it is an important forage and range grass in parts of Africa, including South Africa. It was introduced into many of the arid subtropical regions of the world, primarily Australia, North America, and South America, and today the species is grown on more than 50 million ha worldwide [3].

\footnotetext{
${ }^{*}$ Corresponding author: Mohamedalmontasir A. M. Mohamed

Department of Range Science, Collage of Forestry and Range Science, University of East Kordofan, Sudan. 


\subsection{Description and utilization of buffel grass}

Buffel grass (Cenchrus ciliaris) is a highly variable, tufted tussock-forming perennial grass [4]. It has a deep, tough rootstock that may go as deep as $2 \mathrm{~m}$. Some varieties are rhizomatous. The culms are erect or decumbent, reaching up to $2 \mathrm{~m}$ in length [5]. The leaves are linear blades, green to bluish green, slightly pilose, 3-30 cm long and 4-10 mm wide [6]. It is a very important pasture grass in the tropics, cultivated for permanent pastures and leys in Central Africa, East Africa and northern Australia, and it is widely used as a forage grass in India. The qualities of Cenchrus ciliaris are numerous. It is easy to establish and provides comparatively high value forage with dry matter yields between 2 and 18 t/ha without fertilizer, and up to $24 \mathrm{t} /$ ha with the addition of a complete fertilizer [7]. It makes reasonable quality hay when cut in the early flowering stage, yielding up to $2.5 \mathrm{t} /$ ha per cut. Once the seed has been harvested, old grass can give low quality roughage for drought feeding with supplements. Cenchrus ciliaris is more rarely made into silage, as the moisture content of the grass in semi-arid areas is usually low, it is palatable to stock and once established it can withstand heavy grazing and trampling [4]. One of the best adapted grasses to semi-arid conditions, it is valuable for erosion control in such places. In Australia, it was successfully planted for revegetation and erosion control in parks, reserves and river catchments from the 1960s to the mid-1970s [8].

\section{Material and methods}

This experiment was conducted at Alfashir, on special farm which located South of Alfashir Airport, North Darfur State, at the off rainy season of 2018 and 2019. The objective of the study was to evaluate the effect of different periods of irrigation (DPI) on growth and forage yield of Cenchrus ciliaris. Purity and germination test were carried. Pure live seeds (\%) were determined by using [9] formula. The experimental site was ploughed by using disc plow, leveled and seed beds were well prepared and then the land was divided into four replicates with four plots ( $8 x 5 \mathrm{~m})$ each. The experiment consisted of seed rate of $2 \mathrm{~kg} / \mathrm{ha}$ each [10]. Four treatments were set these include; Irrigating every 7 days ( $\operatorname{Ir}_{1}$ ), Irrigating every 14 days ( $\operatorname{Ir}_{2}$ ), Irrigating every 21 days ( $\left.\operatorname{Ir}_{3}\right)$ and Irrigating every 28 days $\left(\operatorname{Ir}_{4}\right)$. The treatments were randomly assigned to a randomized complete block design (RCBD) with four replicates for statistical analysis.

A quadrate of $1 \mathrm{x} 1 \mathrm{~m}$ was randomly located in each plot for measuring plant density, plant ground cover, plant height and dry matter yield at flowering and maturity stage. Plant density is the number of plants per unit area $\left(\mathrm{m}^{2}\right)$ and the number of plants were counted. Counting was done twice at flowering and maturity stage. Plant ground cover was measured visually as a percent for each plot in relation to the bare soil around. To determine the average plant height, five plants were randomly marked in each treatment for measuring plant height; plant height was taken from the first node to the apical bud of the main stem axis, then the mean of the five plants was obtained in $\mathrm{cm}$. To determine the yield, pasture plants Cenchrus ciliaris within the quadrate was clipped at $5 \mathrm{~cm}$ above the ground surface, and put inside paper bags and dried by air.

\section{Results and discussion}

As shown in Table No. 1, (DPI) significantly influenced plant density at different growth stages during the two growing seasons, except at the flowering stage of second season in which treatment showed no significant effect on population counts. However, there were significant differences observed in the number of plants among buffel grass. These results are in agreement with [11]. Table No. 2 shows that the number of irrigations and the quantities of water applied were significantly effects on plant ground cover. This is due to the difficulty of plant growth in the early stages of its life on the one hand and on the other hand to the small size of the root mass with limit vegetation cover. In fact, the evaporation of water exceeds the capacity of the root mass absorption, which requires more water [12]. DPI showed significant effect on plant height among the different treatments. However, ir 1 and $\operatorname{ir}_{2}$ significantly increased plant height in relation to other treatments at different stages of growth during the two growing season as shown in Table No. 3. However, ir 1 and $i_{2}$ showed better performance during both seasons among the other treatments, this due to the more water, the more leaves and tillers, this agreed with [1] who stated that the change in soil moisture content is influence crop production. As shown in Table No. 4, number of irrigation were significantly increased dry matter yield, there was as a result of different period of irrigation. The more water, the more leaves and tillers, the number of tillers and leaves in a grass plant determines the rate of biomass accumulation and the quality of forage [13]. Also the change in soil moisture content is influence crop production, this agreed with [1]. 
Table 1 Effect of irrigation on plant density

\begin{tabular}{|c|c|c|c|c|}
\hline & \multicolumn{2}{|l|}{2018} & \multicolumn{2}{|l|}{2019} \\
\hline & Flowering stage & Maturity stage & Flowering stage & Maturity stage \\
\hline \multicolumn{5}{|c|}{ Treatment } \\
\hline $\mathrm{Ir}_{1}$ & 117.2 & 117 & 122.3 & 120.5 \\
\hline $\mathrm{Ir}_{2}$ & 106.5 & 105.8 & 101.2 & 101 \\
\hline $\operatorname{Ir}_{3}$ & 91.7 & 88.2 & 100.3 & 93.9 \\
\hline $\mathrm{Ir}_{4}$ & 92 & 74.4 & 81.1 & 55.7 \\
\hline $\mathrm{SE} \pm$ & $2.03^{*}$ & $3.21^{*}$ & $1.26^{\mathrm{ns}}$ & $1.44^{*}$ \\
\hline
\end{tabular}

Table 2 Effect of irrigation on plant ground cover

\begin{tabular}{|l|l|l|l|l|}
\hline \multirow{2}{*}{} & \multicolumn{2}{|l|}{$\mathbf{2 0 1 8}$} & $\mathbf{2 0 1 9}$ \\
\cline { 2 - 5 } & Seedling stage & Flowering stage & Seedling stage & Flowering stage \\
\hline Treatment & \multicolumn{5}{|l|}{} \\
\hline Ir1 & 85.1 & 93.2 & 90.1 & 95.4 \\
\hline Ir2 & 78.1 & 77.4 & 84.2 & 86.7 \\
\hline Ir3 & 60.3 & 60.8 & 72.5 & 69.2 \\
\hline Ir4 & 58.7 & 50.2 & 66.2 & 48.3 \\
\hline SE+ & $1.11^{*}$ & $0.96^{*}$ & $1.06^{*}$ & $1.76^{* *}$ \\
\hline
\end{tabular}

Table 3 Effect of irrigation on plant height

\begin{tabular}{|c|c|c|c|c|}
\hline & \multicolumn{2}{|l|}{2018} & \multicolumn{2}{|l|}{2019} \\
\hline & Flowering stage & Maturity stage & Flowering stage & Maturity stage \\
\hline \multicolumn{5}{|c|}{ Treatment } \\
\hline Ir1 & 111.7 & 131 & 115.2 & 126.8 \\
\hline Ir2 & 104.2 & 106.1 & 109.4 & 125.6 \\
\hline Ir3 & 87.3 & 89.3 & 85.2 & 88.4 \\
\hline Ir4 & 50.6 & 51.1 & 68.5 & 68.9 \\
\hline SE+ & $1.11^{*}$ & $1.21^{*}$ & $1.89 *$ & $1.17^{*}$ \\
\hline
\end{tabular}

Table 4 Effect of irrigation on dry matter yield

\begin{tabular}{|l|l|l|}
\hline Treatment & $\mathbf{2 0 1 8}$ & $\mathbf{2 0 1 9}$ \\
\hline $\mathrm{Ir}_{1}$ & 1856.4 & 2013.6 \\
\hline $\mathrm{Ir}_{2}$ & 1698.1 & 1898.1 \\
\hline $\mathrm{Ir}_{3}$ & 909.7 & 1213.7 \\
\hline $\mathrm{Ir}_{4}$ & 897.1 & 1198.3 \\
\hline $\mathrm{SE} \pm$ & $0.95^{*}$ & $1.46^{* *}$ \\
\hline
\end{tabular}

ns not significant, ${ }^{*}$ significant at 0.05 level, ${ }^{* *}$ significant at 0.01 level 


\section{Conclusion}

This study was conducted to evaluate the effect of different periods of irrigation (DPI) on growth and forage yield of buffel grass Cenchrus ciliaris. DPI showed significant effect on plant density, plant ground cover, Plant height and dry matter yield. The study showed that irrigation every 7 days (Ir1) was suitable for buffel grass at semi-arid zone in Sudan specially on hot months.

\section{Compliance with ethical standards}

\section{Acknowledgments}

The authors would like to thank anonymous reviewers for constructive comments on the manuscript.

\section{Disclosure of conflict of interest}

The authors declare that there is no conflict of interest.

\section{References}

[1] SA Ahmed. Effect of Weed Control on Growth and Seed Production of Butterfly Pea (Clitoria ternatea) Under Rainfed Conditions at Zalingei Western Darfur State - Sudan. ARPN Journal of Science and Technology. 2013; $3(5)$.

[2] CW Hanselk. 1988. Buffelgrass-South Texas wonder grass Rangelands. 1988; 10: 279-281.

[3] CW Hanselka, MA Hussey FF. Ibarra Buffel grass L.E. Moser (Ed.), Warm-season (C4) Grasses, Agronomy Monograph, 45, ASA, CSSA, and SSSA, Madison, WI. 2004; 477-502.

[4] Food \& Agricultural Organization (FAO). Grassland Index. A searchable catalogue of grass and forage legumes. FAO, Rome, Italy. 2010.

[5] Cook BG, Pengelly BC, Brown SD, Donnelly JL, Eagles DA, Franco MA, Hanson J, Mullen BF, Partridge IJ, Peters M and Schultze-Kraft R. Tropical forages. CSIRO, DPI\&F (Qld), CIAT and ILRI, Brisbane, Australia. 2005.

[6] Clayton WD, Harman KT, Williamson H. Grass Base - The Online World Grass Flora. The Board of Trustees, Royal Botanic Gardens, Kew. 2006.

[7] Osman AE, Makawi M, Ahmed R. Potential of the indigenous desert grasses of the Arabian Peninsula for forage production in a water-scarce region. Grass and Forage Sci. 2008; 63(4): 495-503.

[8] Payne AL, Watson IW, Novelly PE. Spectacular recovery in the Ord River catchment. Miscellaneous Publication 17/2004, Department pf Agriculture, Perth, Western Australia. 2004.

[9] Whiteman PC. Tropical Pasture Science. Oxford University Press, New York, USA. 1980; 633.

[10] Hacker JB, Williams RJ, Coote JN. Productivity in late winter and spring of four cultivars and 21 accessions of Cenchrus ciliaris and Digitaria eriantha cv. Premier. Tropical Grasslands. 1995; 29: 28-33.

[11] Koech OK, Kinuthia RN, Karuku GN, Mureithi SM, Wanjogu R. Irrigation levels affects biomass yields and morphometric characteristics of range grasses in arid rangelands of Kenya. Springer Plus. 2016; 5: 1640.

[12] Khader BA, Gamhuryah AA, Omer SL, Zahrah AE and Azaiez OB. Yield and Irrigation Water Productivity of Three Varieties of Buffel Grass (Cenchrus ciliaris L.) in the Southern Coastal Plains of Yemen. Journal of Agricultural Science. 2018; 10(1): 114-121.

[13] Skinner HR, Moore KJ. Growth and development of forage plant. In R. F. Barnes, C. J. Nelson, K. J. Moore, \& M. Collins (Eds.), Forages: The science of grassland agriculture (6th ed., pp. 53-66). Wiley-Blackwell, Ames. 2007. 